\title{
A Study on Extent of Farm Mechanization in North Bank Plains Agro- Climatic Zone of Assam
}

\author{
A. Rajkhowa ${ }^{1}$, I. $\operatorname{Barman}^{1 *}$, P. K. Das ${ }^{1}$, R. Das ${ }^{2}$, S. D. Deka ${ }^{3}$, \\ A. Sonowal ${ }^{5}$, A. Khound ${ }^{4}$ and R. Paul ${ }^{4}$ \\ ${ }^{1}$ Department of Extension Education, ${ }^{2}$ Department of Agri Eco \&Farm Management, \\ ${ }^{3}$ Department of Agril. Statistics, ${ }^{4}$ Department of Agri. Engineering, Biswanath College of \\ Agriculture, AAU, Assam, India \\ ${ }^{5}$ Agricultural. Engineer, AICRPDA, AAU, Assam, India \\ *Corresponding author
}

\section{A B S T R A C T}

\section{Ke ywords \\ Farm \\ Mechanization, \\ Farm Size, \\ Mechanization \\ Index, Sonitpur, \\ Udalguri, Assam \\ Article Info \\ Accepted: \\ 04 August 2020 \\ Available Online: \\ 10 September 2020}

\begin{abstract}
Farm mechanization plays an important role for effective utilization of inputs which ultimately increase the productivity of land and labour by reducing the drudgery in farm operations in agriculture. There has been a substantial progress farm mechanization in India; however, its spread has been in the most uneven manner. Further, efforts to identify specific farm equipment, implements and machines, for different agro climatic zones, as well as their promotion in the respective zones has been lacking The study was conducted in Sonitpur and Udalguri districts under North Bank Plain Agro-Climatic Zone of Assam with 160 farmers to determine the extent of farm mechanization across different farm size groups. The findings revealed that majority of marginal (64.86\%), small (64.52\%), medium (72\%) and large (72.73\%) farmers had medium level of farm mechanization. In case of pooled sample, majority $(67.5 \%)$ of the respondents had medium level of farm mechanization. The findings of the study indicated that majority of the respondents belonged to medium mechanization category. It implies that concerned agencies/ organizations should put more efforts in accelerating the adoption of farm mechanization by the farmers for sustainable agricultural production
\end{abstract}

\section{Introduction}

The farming scenario of Indian agriculture is changing day by day. Initially (just after independence) Indian agriculture attributes as bullock based farming practices. Government of India has initiated various schemes to rebuild the farming system to adopt the advance science and technological practices in farming. The Indian scenario relating to use of farm machineries in various region differ significantly from each other. During last 53 years the average farm power availability in India has increased from about $0.30 \mathrm{kw} / \mathrm{ha}$ in 1960- 61 to about $2.02 \mathrm{kw} / \mathrm{ha}$ in 2013-14. 8000 tractors were produced in the year 195051.But in the year 2013, India produce 619,000 tractors accounting for $29 \%$ of 
world's output. Power tiller was introduced in the country in the sixties, but could not gain popularity like tractor due to its limitation in the field and on the road (Singh et al., 1999). The term "Farm mechanization" refers to the use of suitable tools, implements and machinery in agricultural activities with the aim of improving the productivity of farm labour and land. The tools, implements and machinery may need either human, animal, mechanical or electrical power, or a combination of these as the source of power (Sims and Kienzle, 2016).

There has been a substantial progress farm mechanization in India; however, its spread has been in the most uneven manner. Further, efforts to identify specific farm equipment, implements and machines, for different agro climatic zones, as well as their promotion in the respective zones has been lacking. The Ministry of Agriculture \& farmer Welfare, Government of India is giving a focus to farm mechanization including $\mathrm{R} \& \mathrm{D}$, custom hiring and better technology infusion, through its various schemes. But this progress of mechanization shows that mechanization of agriculture in India is very much confined among the rich farmers and the small and marginal farmers remain totally untouched. Moreover, the growth of farm mechanization in India in comparison to that of advanced countries is found not very significant. Again whatever farm mechanization that has been reported, it is very much confined among the states like Punjab, Haryana and Western Uttar Pradesh, whereas other states could not reap much benefit from it.

In north-eastern states, the level of mechanization is extremely low. There are a number of reasons behind this. Factors such as hilly topography, high transportation cost, lack of state financing and other financial constraints due to socio-economic conditions and dearth of agricultural machinery manufacturing industries have hindered the growth of farm equipment sector within these states. Farm power, available at $0.66 \mathrm{HP} / \mathrm{ha}$, in Assam is meager. Most of the available power also comes from drought animal (about 80 percent). In spite of state government plan to increase the farm power availability to 1.30 HP/ha by the end of $11^{\text {th }}$ five year plan, animal power will remain a major source of farm power in Assam, especially for smallscale farmers. Therefore the question of what level of technology is to be adopted for an effective farm mechanization programme is of utmost importance especially in the context of use of machinery in small farms (Barua and Das, 2015). In case of north-eastern region, Department of Agriculture and Farmers Welfare is implementing a scheme for Promoting Agricultural Mechanization through "Outsourcing of training and demonstrations of newly developed equipments". Beside above interventions, the Department is promoting Farm Mechanization by making agricultural equipment available among farmers at cheaper rates. A level of $25-50 \%$ subsidy on procurement cost is made available under revised "Macro Management of Agriculture (MMA)" scheme for different categories of equipment. In addition, the Govt. of Assam has launched a new Scheme "Chief Minister Samagra Gramyana Unnayan Youjana (CMSGUY)" to be implemented over a period of five years from 2016-17 and culminating in the year 2021-212 with an objective to achieve desired growth of Agricultural Mechanization by providing one Tractor to each revenue village. As a result of different programmes implemented by the Government of India, State Government over the years and equal participation from Private Sector, the level of mechanization has been increasing steadily over the years. Labour availability crisis along with the need to ensure food security in the country, the benefits of farm mechanization makes it a 
crucial component of shaping the future of the Indian agriculture. Keeping these facts in view, the present study was undertaken to determine the extent of farm mechanization across different farm size groups in North Bank Plains Agro-Climatic Zone of Assam

\section{Materials and Methods}

The present study was conducted in Udalguri district and Sonitpur district selected at random under North Bank Plain Agro Climatic Zone of Assam. A proportionatecum-random sampling (probability proportionate to size) technique was followed for selection of 160 respondents which constituted the sample for the study. Data for the study were collected with the help of personal interview method with the help structured schedule. The percentage, frequency, mean, standard deviation and coefficient variation were used in statistical analysis and interpreting data.

Farm mechanization is defined as the development and introduction of mechanized assistance of all forms and at any level of sophistication in agricultural production to improve efficiency of human time and labour (Starkey, 1998).

In the present study farm mechanization was measured with the help of Mechanization Index (MI) as suggested by Nowacki, 1974 and Singh, 2006. Mechanization index (MI) was expressed the percentage of machine work $\left(\mathrm{E}_{\mathrm{M}}\right)$ to the sum of manual $\left(\mathrm{E}_{\mathrm{H}}\right)$, animal $\left(E_{\mathrm{A}}\right)$ and machine work $\left(\mathrm{E}_{\mathrm{M}}\right)$ expressed in energy units.

A mechanization index based on the matrix of use of animate and mechanical energy inputs can be expressed as follows.

$$
M I_{E=}{ }^{\frac{E_{M}}{E_{T}}}=\frac{E_{M}}{E_{H}+E_{A}+E_{M}} \times 100 \%
$$

Where,

$M I_{E}=$ Mechanization Index $(\%)$

$E_{M}=$ Sum of averages of all mechanical operational works of the machine in $\mathrm{kWhr} / \mathrm{ha}$

$E_{T}=$ Sum of all average work outlays in $\mathrm{kWhr} /$ ha by animals $\left(E_{A}\right)$, human $\left(E_{H}\right)$, and tractor powered machines $\left(E_{M}\right)$.

$E_{H}$ is the average energy input of work provided exclusively by human power (labour) per hectare: it was worked out as shown below.

$E_{H}=0.1 . \mathrm{NH} . \mathrm{TH} / \mathrm{A}$

where;

$E_{H}=$ average energy input or work provided per hectare by human labour $(\mathrm{kWhr} / \mathrm{ha}) \mathrm{NH}=$ average number of labour employed

$\mathrm{TH}=$ average rated working time devoted to manual operation (hours) $0.1=$ Theoretical average power of an average man working optimally

$\mathrm{A}=$ Area of land cultivated (ha)

$E_{M}$ represents the first degree of mechanization, motorized machinery coexisting with a high participation of operators. It was worked out as;

$E_{M}=0.2 . \mathrm{NM} . \mathrm{TM} / \mathrm{A}$

where

$E_{M}=$ Average energy input or work per hectare by motorized machines $(\mathrm{kWhr} / \mathrm{ha})$

$0.2=$ Corrector co- efficient of the tractorpowered machine. 
$\mathrm{NM}=$ rated working power of the tractor $(\mathrm{kW})$

$\mathrm{TM}=$ rated working time of the motorized energy source, $\mathrm{hr} / \mathrm{ha} \mathrm{A}=$ Area worked in hectare by motorized machines.

$E_{A}$ is the average energy input of work provided exclusively by animal power per hectare. It was worked out as;

$E_{A}=0.5 . \mathrm{NA} . \mathrm{TA} / \mathrm{A}$

where;

$E_{A}=$ average energy input or work provided per hectare by animal $(\mathrm{kWhr} / \mathrm{ha}) \mathrm{NA}=$ total number of animal

$\mathrm{TA}=$ average rated working time for manual operation (hours) $0.5=$ Theoretical average power of an animal working optimally $\mathrm{A}=$ Area of land cultivated (ha)

Based on the mean ( $\bar{X})$ and standard deviations (S.D) of the total mechanization index score obtained by the respondent were classified into following three categories:

\begin{tabular}{|l|lr|l|}
\hline $\begin{array}{l}\text { Sl. } \\
\text { No. }\end{array}$ & Categories & Range \\
\hline $\mathbf{1 .}$ & $\begin{array}{l}\text { Low farm } \\
\text { mechanization }\end{array}$ & Up to $(\overline{\mathrm{X}}-1$ S.D $)$ \\
\hline $\mathbf{2 .}$ & $\begin{array}{l}\text { Medium } \\
\text { mechanization }\end{array}$ & $\begin{array}{l}\overline{\bar{X}}-1 \quad \text { S.D }) \quad \text { to } \\
\overline{(}+1 \text { S.D })\end{array}$ \\
\hline 3. & $\begin{array}{l}\text { High } \\
\text { mechanization }\end{array}$ & farm & Above $(\bar{X}+1$ S.D $)$ \\
\hline
\end{tabular}

\section{Results and Discussion}

\section{Extent of farm mechanization across different farm size groups}

To assess the extent of farm mechanization, a mechanization index was worked out. Mechanization index was expressed the percentage of machine work $\left(E_{M}\right)$ to the sum of manual $\left(\mathrm{E}_{\mathrm{H}}\right)$, animal $\left(\mathrm{E}_{\mathrm{A}}\right)$ and machine work $\left(E_{M}\right)$ expressed in energy units.

Table 1 reveals that in case of pooled farmers; majority of the respondents $(67.50 \%)$ belonged to medium mechanization category, followed by 22.5 per cent to low mechanization category and remaining 10 per cent belonged to high mechanization category. As regards marginal farmers; majority of the respondents (64.86\%) belonged to medium mechanization category, followed by 24.32 per cent to low mechanization category and remaining 10.81 percent belonged to high mechanization category. As regards small farmers; 64.52 per cent were medium mechanization category. A sizeable proportion of them (24.19\%) had low mechanization status. Only 11.29 per cent of them were highly mechanized.

In case of medium farmers; 72 per cent of the respondents belonged to the medium mechanization category followed by 20 per cent of them belonged to low mechanization category. Only 8 percent of the respondent belonged to high mechanization category. As regards large farmers; majority of the respondents $(72.73 \%)$ belonged to medium mechanization category, followed by 18.18 per cent to low mechanization category and remaining 9.09 percent belonged to high mechanization category.

The highest mean mechanization score (0.94) was obtained for medium and large farmers and lowest (0.89) for marginal farmers. All the mean scores indicated medium level of farm mechanization. The probable reason of above finding might be that the farmers had good educational status, medium level of economic motivation, medium level of availability of working capital. The values of coefficients of variation indicated that the respondents were highly homogeneous with respect to their farm mechanization. 
Table 2 indicates about the major farm machineries that were owned by sample farmers across different farm size. A total of 6 farmers were found to own tractor. Out of which 3 were medium, 1 was small and 2 were belonged to large category farmers. A total of 13 farmers were found to own power tiller. Out of which 2 were small, 6 were medium and 5 were belonged to large farmers. A sizeable (81) of the sample farmers were found to own country plough. Out of which 10 were marginal, 28 were small, 35 were medium and 8 were belonged to large farmers. A total of 34 farmers were found to own MB plough. Out of which 1 was marginal, 12 were small, 15 were medium and 6 were belonged to large farmers. A total of 26 farmers were found to own cultivator. Out of which 2 were marginal, 10 were small, 9 were medium and 5 were belonged to large farmers. A total of 14 farmers were found to own rotavator. Out of which 3 were small, 7 were medium and 4 were belonged to large farmers. A total of 21 farmers were found to own disc plough. Out of which 2 were marginal, 7 were small, 9 were medium and 3 were belonged to large farmers. A total of 14 farmers were found to own leveller. Out of which 1 was marginal, 5 were small, 5 were medium and 3 were belonged to large farmers. A total of 8 farmers were found to own puddler. Out of which 1 was small, 5 were medium and 2 belonged to large farmers. A total of 13 farmers were found to own harrow. Out of which 4 were small, 6 were medium and 3 belonged to large farmers. A total of 3 farmers were found to own harrow. Out of which, 2 were medium and 1 belonged to large farmers. Majority (117) of sample farmers were found to have wheel hoe. Out of which 20 were marginal, 42 were small, 46 were medium and 9 belonged to large farmers. A total of 18 farmers were found to have electric pump sets. Out of which 2 were marginal, 3 were small, 6 were medium and 7 belonged to large farmers. A total of 23 farmers were found to own diesel pump sets. Out of which 8 were small, 10 were medium and 5 belonged to large farmers. All the sample 160 farmers were found to have Knapsack sprayer. Out of which 37 were marginal, 62 were small, 50 were medium and 11 belonged to large farmers. Only 1 medium farmer was found to owned paddy thresher.

Table.1 Distribution of respondents according to extent of farm mechanization

\begin{tabular}{|c|c|c|c|c|c|c|}
\hline Category & $\begin{array}{c}\text { MI } \\
\text { Range }\end{array}$ & $\begin{array}{l}\text { Marginal } \\
(\%)\end{array}$ & $\begin{array}{c}\text { Small } \\
(\%)\end{array}$ & $\begin{array}{l}\text { Medium } \\
(\%)\end{array}$ & $\begin{array}{c}\text { Large } \\
(\%)\end{array}$ & $\begin{array}{c}\text { Total } \\
(\%)\end{array}$ \\
\hline $\begin{array}{c}\text { Low } \\
\text { mechanization }\end{array}$ & $\begin{array}{c}0.87- \\
0.90\end{array}$ & $\begin{array}{c}9 \\
(24.32)\end{array}$ & $\begin{array}{c}15 \\
(24.19)\end{array}$ & $\begin{array}{c}10 \\
(20)\end{array}$ & $\begin{array}{c}2 \\
(18.18)\end{array}$ & $\begin{array}{c}36 \\
(22.5)\end{array}$ \\
\hline $\begin{array}{c}\text { Medium } \\
\text { mechanization }\end{array}$ & $\begin{array}{l}0.91- \\
0.96\end{array}$ & $\begin{array}{c}24 \\
(64.86)\end{array}$ & $\begin{array}{c}40 \\
(64.52)\end{array}$ & $\begin{array}{c}36 \\
(72)\end{array}$ & $\begin{array}{c}8 \\
(72.73)\end{array}$ & $\begin{array}{c}108 \\
(67.5)\end{array}$ \\
\hline $\begin{array}{c}\text { High } \\
\text { mechanization }\end{array}$ & $\begin{array}{c}0.97- \\
0.98\end{array}$ & $\begin{array}{c}4 \\
(10.81)\end{array}$ & $\begin{array}{c}7 \\
(11.29)\end{array}$ & $\begin{array}{c}4 \\
(8)\end{array}$ & $\begin{array}{c}1 \\
(9.09)\end{array}$ & $\begin{array}{c}16 \\
(10)\end{array}$ \\
\hline Total & & $\begin{array}{c}37 \\
(100.00)\end{array}$ & $\begin{array}{c}62 \\
(100.00)\end{array}$ & $\begin{array}{c}50 \\
(100.00)\end{array}$ & $\begin{array}{c}11 \\
(100.00)\end{array}$ & $\begin{array}{c}160 \\
(100.00)\end{array}$ \\
\hline Mean & & 0.89 & 0.93 & 0.94 & 0.94 & 0.93 \\
\hline SD & & 0.01 & 0.03 & 0.02 & 0.02 & 0.03 \\
\hline C.V & & 1.84 & 3.19 & 2.15 & 2.30 & 3.22 \\
\hline
\end{tabular}

* Figures within parenthesis indicate percentage 
Table.2 Major farm machineries owned by farmers across different farm size

\begin{tabular}{|l|l|c|c|c|c|c|}
\hline Sl.No. & $\begin{array}{l}\text { Equipment/ } \\
\text { Machineries }\end{array}$ & $\begin{array}{c}\text { Marginal } \\
(\mathbf{3 7})\end{array}$ & $\begin{array}{c}\text { Small } \\
(\mathbf{6 2})\end{array}$ & $\begin{array}{c}\text { Medium } \\
\mathbf{( 5 0 )}\end{array}$ & $\begin{array}{c}\text { Large } \\
(\mathbf{1 1})\end{array}$ & $\begin{array}{c}\text { Total } \\
\text { farmers (160) }\end{array}$ \\
\hline $\mathbf{1 .}$ & Tractor & - & 1 & 3 & 2 & $\mathbf{6}$ \\
\hline $\mathbf{2 .}$ & Power tiller & - & 2 & 6 & 5 & $\mathbf{1 3}$ \\
\hline $\mathbf{3 .}$ & Country plough & 10 & 28 & 35 & 8 & $\mathbf{8 1}$ \\
\hline $\mathbf{4 .}$ & MB Plough & 1 & 12 & 15 & 6 & $\mathbf{3 4}$ \\
\hline $\mathbf{5 .}$ & Cultivator & 2 & 10 & 9 & 5 & $\mathbf{2 6}$ \\
\hline $\mathbf{6 .}$ & Rotavator & - & 3 & 7 & 4 & $\mathbf{1 4}$ \\
\hline $\mathbf{7 .}$ & Disc plough & 2 & 7 & 9 & 3 & $\mathbf{2 1}$ \\
\hline $\mathbf{8 .}$ & Leveller & 1 & 5 & 5 & 3 & $\mathbf{1 4}$ \\
\hline $\mathbf{9 .}$ & Puddler & - & 1 & 5 & 2 & $\mathbf{8}$ \\
\hline $\mathbf{1 0 .}$ & Harrow & - & 4 & 6 & 3 & $\mathbf{1 3}$ \\
\hline $\mathbf{1 1}$ & Power weeder & - & - & 2 & 1 & $\mathbf{3}$ \\
\hline $\mathbf{1 2 .}$ & Wheel hoe & 20 & 42 & 46 & 9 & $\mathbf{1 1 7}$ \\
\hline $\mathbf{1 3 .}$ & Electric pump sets & 2 & 3 & 6 & 7 & $\mathbf{1 8}$ \\
\hline $\mathbf{1 4}$. & Diesel pump sets & - & 8 & 10 & 5 & $\mathbf{2 3}$ \\
\hline $\mathbf{1 5}$. & Knapsack sprayer & 37 & 62 & 50 & 11 & $\mathbf{1 6 0}$ \\
\hline $\mathbf{1 6 .}$ & Paddy thresher & - & - & $\mathbf{1}$ & - & $\mathbf{1}$ \\
\hline
\end{tabular}

In conclusion the study indicates that there was substantial gap in extent of farm mechanization in sample districts. The findings of the study revealed that majority of the respondents belonged to medium mechanization category. It implies that concerned agencies/ organizations should put more efforts in accelerating the adoption of farm mechanization by the farmers for sustainable agricultural production. On the basis of current findings, the study ultimately would help the policy maker to take appropriate measures for mechanization adoption amongst the farmers which will boost up the agricultural sector as a whole.

\section{References}

Anonymous (2014). Sub-Mission on Agriculture Mechanization. Department of Agriculture \& Cooperation, Government of India.

Adu, E. A., Isiaka, A. A., Awagu, E. F. and Aminu, M.D. (2012). Study On The
Level of Mechanization of Rice Processing In Kano State, Nigeria. International Journal of Engineering Research \& Technology (IJERT). 1(10): 78-81

Barua, P. and Das, P. K. (2015). Farm mechanization in Assam- Prospects \& Policies. Agriculture in Assam. AAU, Jorhat.

Mandal, S., Kumar, A., Singh, R. K. and Ngachan, S.V. (2014). Road Map for Farm Mechanization in Assam State. Indian Journal of Hill Farming. 27(1): 51- 61

Nowacki,T. (1974). Example of Technical Economic Analysis of Mechanized process in various Agro-Technical Conditions: Economic Commission for Europe AGRI/MECH/32

Olaoye, J. O., Rotimi, A. O. (2010). Measurement of Agricultural Mechanization Index and Analysis of Agricultural Productivity of some Farm Settlements in South West, Nigeria. 
Agricultural Engineering International: the CIGR Ejournal. Manuscript 1372. Vol $\mathrm{XII}$

Singh, G. (2006). Estimation of a Mechanization Index and its Impact on Production and Economic Factors - a Case Study in India. Bio Systems
Engineering, 93(1) : 99-106.

Starkey, P. (1998). Integrating Mechanization into Strategies for Sustainable Agriculture. Technical Centre for Agricultural and Rural Cooperation (CTA) Wageningen, the Netherlands

\section{How to cite this article:}

Rajkhowa, A., I. Barman' P. K. Das, R. Das, S. D. Deka, A. Sonowal, A. khound and Paul, R. 2020. A Study on Extent of Farm Mechanization in North Bank Plains Agro-Climatic Zone of Assam. Int.J.Curr.Microbiol.App.Sci. 9(09): 84-90.

doi: https://doi.org/10.20546/ijcmas.2020.909.010 